\title{
Children's and adolescents' reports on their quality of life during the COVID-19 pandemic
}

\author{
Ihsana Sabriani Borualogo, ${ }^{1 *}$ Ferran Casas ${ }^{2,3}$ \\ ${ }^{1}$ Faculty of Psychology Universitas Islam Bandung, Bandung - Indonesia, ${ }^{2}$ Doctoral Program on Education and \\ Society, Faculty of Education and Social Sciences, Universidad Andrés Bello - Chile, ${ }^{3}$ ERIDIqv research team, \\ University of Girona, Girona - Spain
}

\begin{abstract}
COVID-19 affects human life, but very few studies have examined the quality of life of children and adolescents during the pandemic. This article aims to report on the quality of life of children and adolescents $(\mathrm{N}=1,474$; ages 10 -18 years) during the COVID-19 pandemic in Indonesia. Data were collected using Google Forms and convenience sampling. The measuring instrument used measured five domains of quality of life, namely material, physical, social, emotional, and productive wellbeing. The data were analyzed using crosstab, frequency, comparison of mean values, and ANOVA. The results show that children and adolescents have been able to maintain their subjective well-being and adapt to unpleasant situations during the lockdown. Younger boys and girls show significantly higher mean scores than older ones. Children and adolescents reported that they were bored because they had limited physical activities, were dissatisfied with school closures and with what they had learnt at home, and were frustrated by the limited contact they had with friends. The research has implications in providing advice to parents, teachers, children, and adolescents to improve the quality of life of children and adolescents during the pandemic.
\end{abstract}

Keywords: adolescents; children; COVID-19; quality of life

Abstrak: COVID-19 memengaruhi kehidupan manusia, namun masih sangat terbatas studi yang meneliti kualitas hidup anak dan remaja selama pandemik. Artikel ini bertujuan mempresentasikan laporan anak dan remaja ( $\mathrm{N}=1.474$; usia 10-18 tahun) mengenai kualitas hidup mereka selama pandemik COVID-19 di Indonesia. Data dikumpulkan menggunakan Google Form dan convenience sampling. Alat ukur yang digunakan mengukur lima domain kualitas hidup, yaitu kesejahteraan material, fisikal, sosial, emosional, dan produktif. Data dianalisis menggunakan crosstab, frekuensi, membandingkan nilai rerata, dan ANOVA. Hasil menunjukkan bahwa anak dan remaja mampu mempertahankan kesejahteraan subjektif mereka dan beradaptasi dengan situasi yang tidak menyenangkan selama lockdown. Laki-laki dan anak yang lebih muda memperlihatkan secara signifikan nilai rerata yang lebih tinggi dibandingkan perempuan dan anak yang lebih tua. Anak dan remaja melaporkan bahwa mereka bosan karena tidak memiliki variasi aktivitas fisik, tidak puas dengan penutupan sekolah, tidak puas dengan apa yang telah mereka pelajari di rumah, dan tidak puas dengan kontak yang mereka lakukan dengan teman. Penelitian ini memberikan implikasi dalam memberikan saran kepada orang tua, guru, anak, dan remaja untuk meningkatkan kualitas hidup anak dan remaja di masa pandemi ini.

Kata Kunci: anak; COVID-19; remaja; kualitas hidup

\footnotetext{
*Corresponding Author: Ihsana Sabriani Borualogo (ihsana.sabriani@unisba.ac.id), Faculty of Psychology Universitas Islam Bandung, J. Tamansari No. 1, Bandung 40116 - Indonesia.
} 


\section{Introduction}

On March 11, 2020, the World Health Organization (WHO) declared the global and rapid spread of the novel Coronavirus Disease-19 (COVID-19) as a pandemic (World Health Organization, 2020b). Indonesian President Joko Widodo had announced the country's first two confirmed cases on March 2, 2020 (Berita Satu, 2020). The number of COVID-19 cases in Indonesia then increased rapidly. The government instituted lockdowns in several cities aimed at preventing the spread of the virus (News Desk, 2020). Schools were closed, and students began remote learning from home (Sipahutar, 2020).

Various international studies were quick to reveal the effect of lockdown among students and workers (Odriozola-González et al., 2020), the psychological effect of quarantine on youths (Orgilés et al., 2020), and the psychological impact on college students (Cao et al., 2020).

In the Indonesian context, several studies have investigated the impact of COVID-19 on anxiety among the general population (Anindyajati et al., 2021) and health care workers (Setiawati et al., 2021; Sunjaya et al., 2021). However, at the time of writing this article, no studies investigating the quality of life (QoL) of children and adolescents as a life span (and not as different categories of people) during the pandemic in Indonesia had been identified. Children and adolescents are vulnerable to the burden imposed by a lockdown because social contact is crucial to their development (Fegert et al., 2020). While the lockdown in Indonesia was not overly strict, since children and adolescents were compelled to learn remotely and could not physically attend school, they had limited opportunities to meet and interact with their school friends in person.
Children and adolescents can find it difficult to cope with lockdown and social distancing since the experience is typically incongruent with their needs. An online survey in Canada showed that children and adolescents who were deprived of access to their friends and physical activities had a lower subjective well-being (SWB) (Mitra et al., 2021). Another online study, this time in the United States of America, showed that engaging in outdoor physical activities improved adolescents' well-being during the pandemic (Jackson et al., 2021). Thus, while various international studies have revealed the impact of the pandemic on children's and adolescents' well-being and QoL, no such studies have discussed well-being and QoL for Indonesian children and adolescents.

This study therefore aims to investigate children's and adolescents' perceptions of their QoL during the pandemic in Indonesia and hopefully raise awareness among parents, teachers, and policymakers to assist children in improving their well-being. This is essential as studies have shown that SWB decreases with age (Casas \& González-Carrasco, 2019; GonzálezCarrasco et al., 2017). Studies on children's and adolescents' QoL are important given that 25.3\% of the global population comprises children under 15 years old, with $16 \%$ aged 10 to 19 years (UNDP, 2021).

The number of studies on children's and adolescents' QoL increased after data on their SWB was collected through the Children's Worlds International Survey (Rees et al., 2020) and also in the wake of pioneering studies on children's SWB (Ben-Arieh et al., 2014). QoL is a holistic concept that describes how well or poorly life is working at a particular time (Wallander et al., 2001). Wallander et al. (2001, p. 574) defined QoL as “a 
combination of objectively and subjectively indicated well-being in multiple domains of life considered salient in one's culture and time, while adhering to universal standards of human rights."

Children's Worlds uses several domains of life when measuring children's and adolescents' wellbeing to reflect their QoL (Rees et al., 2020). This study uses these domains of QoL as mentioned: material, physical, social, and emotional wellbeing.

Several other studies on the QoL of children and adolescents during pandemics have also employed multiple measurements, including SWB, plus emotional, social, and physical wellbeing (Jackson et al., 2021; Mitra et al., 2021). Felce and Perry suggested five QoL domains: material, physical, social, emotional, and productive well-being (Felce \& Perry, 1997). It is those domains that are used to explain the results of this study.

\section{Method}

This study used a survey design and explained the results descriptively using ANOVA.

\section{Procedure}

An internet-based study was conducted between May and July 2020. Data were collected using a Google Form sent to parents with children aged between 10 and 18 years. The age of the sample was set at 10-18 years as 10 is the lowest age for which instruments have been tested (Borualogo \& Casas, 2019; Casas \& GonzálezCarrasco, 2019; Casas \& González, 2017; González-Carrasco et al., 2017). A Google Form named Coronavirus and Quality of Life of Children and Adolescents was distributed via parents' WhatsApp groups to obtain consent for their children to participate in the study. The form contained instructions for the parents to pass it to their children, and for the children to then complete the questionnaire. Thus, after giving their consent, the parents passed the Google Form to their children. The children and adolescents were also informed that their data would be treated confidentially and that they could decline to answer the questions. After the children and adolescents had indicated their agreement to participate, they clicked a button and began answering the items. Their answers were submitted automatically to the research team.

Sampling

Convenience sampling of children and adolescents aged 10-18 was adopted. Table 1 displays the participants by Indonesian province.

\section{Instruments}

The instruments used to assess QoL were selected based on the domains suggested by Felce and Perry (1997). Some of the items were taken from psychometric scales, and Cronbach's alpha is also reported. All of the instruments used in this study were adapted to the Indonesian context in line with Borualogo et al. (2019). Each instrument has been tested on children and adolescents in focus group discussions with back translation methods used to ensure construct validity. Several items have already been used in the Children's Worlds survey in Indonesia (Borualogo \& Casas, 2019, 2021a, 2021b). Details concerning the adaptation process can be found in Borualogo et al. (2019) and Borualogo and Casas (2019). 


\section{Table 1}

Participants by Province in Indonesia

\begin{tabular}{|c|c|c|}
\hline Province & $\mathrm{n}$ & $\%$ \\
\hline West Java & 1,011 & 68.4 \\
\hline East Java & 38 & 2.6 \\
\hline Central Java & 25 & 1.7 \\
\hline Special District of Yogyakarta & 10 & 0.7 \\
\hline Banten & 74 & 5.0 \\
\hline Jakarta & 89 & 6.0 \\
\hline North Sumatra & 67 & 4.5 \\
\hline West Sumatra & 21 & 1.4 \\
\hline South Sumatra & 18 & 1.2 \\
\hline Bangka Belitung & 7 & 0.5 \\
\hline Riau & 15 & 1.0 \\
\hline Jambi & 9 & 0.6 \\
\hline Lampung & 5 & 0.3 \\
\hline Bengkulu & 8 & 0.5 \\
\hline Special District of Aceh & 3 & 0.2 \\
\hline South Sulawesi & 16 & 1.1 \\
\hline Southeast Sulawesi & 2 & 0.1 \\
\hline West Sulawesi & 1 & 0.1 \\
\hline Gorontalo & 1 & 0.1 \\
\hline West Kalimantan & 2 & 0.1 \\
\hline South Kalimantan & 3 & 0.2 \\
\hline North Kalimantan & 1 & 0.1 \\
\hline Central Kalimantan & 2 & 0.1 \\
\hline East Kalimantan & 6 & 0.4 \\
\hline Maluku & 1 & 0.1 \\
\hline West Papua & 2 & 0.1 \\
\hline Bali & 8 & 0.5 \\
\hline East Nusa Tenggara & 1 & 0.1 \\
\hline Unidentified & 28 & 1.9 \\
\hline Total & 1,474 & 100 \\
\hline
\end{tabular}

Children and adolescents were asked whether they had heard of the Coronavirus (options: yes, no, and don't know) and their knowledge about it $(1=$ No knowledge; $2=\mathrm{I}$ know a little; 3 = I know a lot; 4 = I totally know). Four questions were addressed to identify their sources of information: parents or carers, news and media, institutions, and friends (options: 1 = I do not agree; 2 = I agree a little; 3 = I agree somewhat; 4 = I agree $\mathrm{a}$ lot; 5 = I totally agree; and don't know).

\section{Material well-being}

Two questions were used to assess material well-being. These enquired as to (1) concern of how important it is to find a solution for family 
money issues, and (2) how worried they were during the last month about their family money (options: for item 1, ranged from $0=$ Not important at all to 10 = Totally important; for item 2 , ranged from $0=$ Not worried at all to $10=$ Totally worried).

\section{Physical well-being}

Children and adolescents were asked how satisfied they were with how they normally spent their time before and during the pandemic. The options ranged from $0=$ Not at all satisfied to $10=$ Totally satisfied. They were also asked about various activities (e.g., helping out in the household, playing games) (options: 1 = Never, 2 = Once a day, 3 = Several times a day, $4=$ Once a week).

\section{Social well-being}

Five questions were used to measure social well-being: (1) whether they could go outdoors, (2) whether they could stay in touch with friends, (3) the modes of communication used to keep in touch with friends during the lockdown, (4) how satisfied they were with the contact they had with friends, and (5) how much adults let them participate in conversations about Coronavirus. The possible answers were as follows. Questions 1 and 2: yes, no, don't know; Question 3: modes of communication such as voice call, video call, WhatsApp; Question 4: ranged from $0=$ not at all satisfied to $10=$ Totally satisfied; Question 5: ranged from $0=$ Not at all to $10=$ Totally.

\section{Emotional well-being}

The Children's Worlds Positive and Negative Affect Scale (CW-PNAS) was used and included three items for PA (happy, calm, and full of energy) and three items for NA (sad, stressed, and bored) (Rees et al., 2020). The CW-PNAS evaluated children's feelings over the previous two weeks on a scale of 0-10. For this sample, Cronbach's alpha was .698 for PA and .658 for NA.

Children and adolescents were also asked how worried they were during the last month about (1) getting infected by the virus, (2) someone they knew getting infected by the virus, (3) their family's money, (4) the changing status of their study at school, and (5) if someone might hurt them. The options were 0 to 10 , where $0=$ Not worried at all and $10=$ Totally worried. Cronbach's alpha $=.778$.

Two questions asked about their worries on what was happening in Indonesia at that time and whether they thought their worries were heard (options: 1 = I do not agree; $2=\mathrm{I}$ agree $\mathrm{a}$ little; 3 = I agree somewhat; 4 = I agree a lot; 5 = I totally agree; 6 = Don't know).

\section{Productive well-being}

Four questions were used to measure the children's and adolescents' satisfaction with (1) not going to school during the COVID-19 pandemic, (2) the things they learned at home, (3) how they normally spent their time before the COVID-19 pandemic, and (4) how they spent their time during the COVID-19 pandemic (options: ranged from $0=$ Not at all satisfied to $10=$ Totally satisfied); Cronbach's alpha = .781.

The participants were asked how they studied at home due to the closure of all schools. Several possibilities were presented (e.g., online learning, learning through national TV) (options: Yes or No).

They were also asked how important they thought it was to find a solution for (1) the Coronavirus, (2) family money, and (3) feeling safe so they would not feel threatened (options: 0 $=$ not important at all to $10=$ totally important). 


\section{Children's Worlds Subjective Well-Being Scale}

The Children's Worlds Subjective Well-Being Scale (CW-SWBS) is a multi-item, context-free psychometric scale that has been translated and validated into Indonesian (Borualogo \& Casas, 2019). It includes five original items with responses on an 11-point scale from 0 to 10 . For Indonesian, the original fit indices were $\chi^{2}=94.58$, $d f=5, p=.000$, comparative fit index (CFI) $=.988$, and root mean square error of approximation (RMSEA) = .049 (.041-.058) (Borualogo \& Casas, 2019). Cronbach's alpha for this sample was 930.

Analysis

Mean scores, cross-tabulations, and frequencies were calculated with SPSS 23 to provide an overview of children's and adolescents' perceptions and evaluations of their QoL during the COVID-19 pandemic by gender and school grade. Mean differences were tested using ANOVA.

\section{Results}

Table 2 displays participants in the study by gender and school grade: $59.9 \%$ were girls, $47.2 \%$ were high school students, and the average age was $14.73(\mathrm{SD}=2.74)$.

A total of $98.8 \%$ of children and adolescents reported they had heard about the Coronavirus, as shown in Table 3. More girls (48.1\%) reported that they knew a lot about Coronavirus rather than boys (44.7\%), as seen in Table 4. Moreover, high school students $(57.7 \%)$ reported that they knew a lot more about Coronavirus rather than middle school students (44.6\%) and elementary students (29.5\%).

The result analysis in Table 5 shows that the elementary students $(\mathrm{M}=4.01 ; \mathrm{SD}=0.92)$ showed higher mean scores than the middle school students ( $\mathrm{M}=3.96$; $\mathrm{SD}=0.95)$ and high school students $(M=3.75$; $S D=1.00)$ in terms of how well informed they felt about the pandemic through parents and carers.

Table 2

Study Participants by Gender and School Grade

\begin{tabular}{lrrrrrrr}
\hline & \multicolumn{2}{c}{ Girls } & \multicolumn{2}{c}{ Boys } & \multicolumn{2}{c}{ Total } \\
\cline { 2 - 7 } & $\mathrm{n}$ & $\%$ & $\mathrm{n}$ & $\%$ & $\mathrm{n}$ & $\%$ \\
\hline Elementary & 216 & 14.7 & 177 & 12.0 & 393 & 26.7 \\
Middle school & 218 & 14.8 & 168 & 11.4 & 386 & 26.2 \\
High school & 449 & 30.5 & 246 & 16.7 & 695 & 47.2 \\
\hline Total & 883 & 59.9 & 591 & 40.1 & 1,474 & 100 \\
\hline
\end{tabular}

Table 3

Percentage of Children and Adolescents that Had Heard about Coronavirus

\begin{tabular}{lrrrrrrrr}
\hline & \multicolumn{2}{c}{ Yes } & \multicolumn{2}{c}{ No } & \multicolumn{2}{c}{ Don't Know } & \multicolumn{2}{c}{ Total } \\
\cline { 2 - 9 } & $\mathrm{n}$ & $\%$ & $\mathrm{n}$ & $\%$ & $\mathrm{n}$ & $\%$ & $\mathrm{n}$ & $\%$ \\
\hline Girls & 873 & 98.9 & 10 & 1.1 & 0 & 0 & 883 & 100 \\
Boys & 583 & 98.6 & 3 & 0.5 & 5 & 0.8 & 591 & 100 \\
Elementary & 390 & 99.2 & 1 & 0.3 & 2 & 0.5 & 393 & 100 \\
Middle school & 381 & 98.7 & 4 & 1.0 & 1 & 0.3 & 386 & 100 \\
High school & 685 & 98.6 & 8 & 1.2 & 2 & 0.3 & 695 & 100 \\
\hline Total & 1,456 & 98.8 & 13 & 0.9 & 5 & 0.3 & 1,474 & 100 \\
\hline
\end{tabular}


Children's and adolescents' reports on their quality of life ....

Table 4

Children's and Adolescents' General knowledge about the Coronavirus by Gender and School Grade

\begin{tabular}{lcccccccccc}
\hline & \multicolumn{2}{c}{$\begin{array}{c}\text { Not at all } \\
\text { knowing }\end{array}$} & \multicolumn{2}{c}{ Know a little } & \multicolumn{2}{c}{ Know a lot } & \multicolumn{2}{c}{ Totally know } & \multirow{2}{*}{ Total } \\
\cline { 2 - 11 } & $\mathrm{n}$ & $\%$ & $\mathrm{n}$ & $\%$ & $\mathrm{n}$ & $\%$ & $\mathrm{n}$ & $\%$ & $\mathrm{n}$ \\
\hline Girls & 4 & 0.5 & 378 & 42.8 & 425 & 48.1 & 76 & 8.6 & 883 & 100 \\
Boys & 5 & 0.8 & 284 & 48.1 & 264 & 44.7 & 38 & 6.4 & 591 & 100 \\
Elementary & 4 & 1.0 & 241 & 61.3 & 116 & 29.5 & 32 & 8.1 & 393 & 100 \\
Middle school & 3 & 0.8 & 186 & 48.2 & 172 & 44.6 & 25 & 6.5 & 386 & 100 \\
High school & 2 & 0.3 & 235 & 33.8 & 401 & 57.7 & 57 & 8.2 & 695 & 100 \\
\hline Total & 9 & 0.6 & 662 & 44.9 & 689 & 46.7 & 114 & 7.7 & 1,474 & 100 \\
\hline
\end{tabular}

\section{Table 5}

Mean Scores of Children's and Adolescents' Well-being Variables by Gender and School Grade

\begin{tabular}{|c|c|c|c|c|c|c|c|c|c|c|c|c|}
\hline & \multicolumn{2}{|c|}{ Girls } & \multicolumn{2}{|c|}{ Boys } & \multicolumn{2}{|c|}{ Elementary } & \multicolumn{2}{|c|}{ Middle School } & \multicolumn{2}{|c|}{ High School } & \multicolumn{2}{|c|}{ Total } \\
\hline & $\mathrm{M}$ & SD & $\mathrm{M}$ & SD & $\mathrm{M}$ & SD & $\mathrm{M}$ & SD & $\mathrm{M}$ & SD & $\mathrm{M}$ & SD \\
\hline 1 & 3.89 & 0.98 & 3.86 & 0.97 & $4.01^{*}$ & 0.92 & $3.96^{*}$ & 0.95 & $3.75^{*}$ & 1.00 & 3.87 & 0.97 \\
\hline 2 & 3.98 & 0.96 & 3.94 & 0.99 & 3.91 & 1.03 & 3.95 & 0.96 & 4.00 & 0.94 & 3.96 & 0.97 \\
\hline 3 & 3.51 & 1.11 & 3.63 & 1.13 & 3.63 & 1.16 & 3.53 & 1.05 & 3.53 & 1.14 & 3.56 & 1.12 \\
\hline 4 & 3.33 & 1.26 & 3.34 & 1.34 & 3.37 & 1.56 & 3.25 & 1.30 & 3.36 & 1.11 & 3.33 & 1.29 \\
\hline 5 & $8.45^{*}$ & 2.11 & $8.06^{*}$ & 2.31 & $7.93^{*}$ & 2.45 & $8.37^{*}$ & 2.00 & $8.45^{*}$ & 2.14 & 8.29 & 2.20 \\
\hline 6 & $7.55^{*}$ & 2.49 & $6.91^{*}$ & 2.68 & $6.98^{*}$ & 2.75 & $7.27^{*}$ & 2.55 & $7.48^{*}$ & 2.49 & 7.29 & 2.58 \\
\hline 7 & 5.99 & 2.56 & 6.25 & 2.67 & $6.31^{*}$ & 2.67 & $6.30 *$ & 2.52 & $5.86^{*}$ & 2.59 & 6.09 & 2.60 \\
\hline 8 & 5.41 & 2.64 & 5.54 & 2.59 & 5.51 & 2.72 & 5.68 & 2.51 & 5.32 & 2.61 & 5.46 & 2.62 \\
\hline 9 & 5.35 & 2.56 & 5.22 & 2.60 & $4.92^{*}$ & 2.73 & $5.47^{*}$ & 2.55 & $5.42^{*}$ & 2.48 & 5.30 & 2.57 \\
\hline 10 & 7.03 & 2.82 & 6.96 & 2.76 & $6.65^{* *}$ & 2.89 & $7.08^{* *}$ & 2.72 & $7.16^{* *}$ & 2.77 & 7.00 & 2.79 \\
\hline 11 & $72.06^{*}$ & 22.08 & $75.01^{*}$ & 19.49 & $77.2^{*}$ & 20.90 & $74.04^{*}$ & 20.13 & $70.55^{*}$ & 21.42 & 73.24 & 21.12 \\
\hline 12 & $6.66^{* *}$ & 2.44 & $6.92^{* *}$ & 2.29 & $7.18^{*}$ & 2.49 & $6.77^{*}$ & 2.32 & $6.53^{*}$ & 2.33 & 6.76 & 2.39 \\
\hline 13 & $5.65^{*}$ & 2.78 & $4.74^{*}$ & 2.85 & $4.58^{*}$ & 3.00 & $5.11^{*}$ & 2.85 & $5.78^{*}$ & 2.65 & 5.29 & 2.84 \\
\hline 14 & $6.54^{*}$ & 2.34 & $7.09 *$ & 2.18 & $6.61^{*}$ & 2.40 & $7.14^{*}$ & 2.17 & $6.63^{*}$ & 2.28 & 6.76 & 2.29 \\
\hline 15 & $5.75^{*}$ & 2.79 & $4.92^{*}$ & 2.74 & $5.04^{*}$ & 3.00 & $5.07^{*}$ & 2.86 & $5.83^{*}$ & 2.59 & 5.42 & 2.80 \\
\hline 16 & 6.49 & 2.45 & 6.71 & 2.42 & $7.04^{*}$ & 2.55 & $6.55^{*}$ & 2.43 & $6.33^{*}$ & 2.34 & 6.58 & 2.44 \\
\hline 17 & $7.63^{*}$ & 2.66 & $6.95^{*}$ & 2.89 & $6.94^{*}$ & 2.94 & $7.44^{*}$ & 2.75 & $7.55^{*}$ & 2.67 & 7.36 & 2.77 \\
\hline 18 & $6.08^{*}$ & 3.22 & $5.36^{*}$ & 3.22 & $5.19 *$ & 3.43 & $5.51 *$ & 3.27 & $6.29 *$ & 3.03 & 5.79 & 3.24 \\
\hline 19 & $7.09 *$ & 2.69 & $6.32^{*}$ & 2.97 & 7.06 & 2.84 & 6.60 & 2.81 & 6.73 & 2.83 & 6.78 & 2.83 \\
\hline 20 & $7.66^{*}$ & 2.55 & $6.86^{*}$ & 2.94 & 7.47 & 2.74 & 7.23 & 2.79 & 7.33 & 2.71 & 7.34 & 2.74 \\
\hline 21 & $7.42^{*}$ & 2.53 & $6.83^{*}$ & 2.84 & 7.04 & 2.72 & 7.12 & 2.66 & 7.29 & 2.66 & 7.18 & 2.67 \\
\hline 22 & $6.34^{*}$ & 3.18 & $5.21^{*}$ & 3.33 & 5.80 & 3.40 & 5.73 & 3.32 & 6.02 & 3.20 & 5.89 & 3.29 \\
\hline 23 & $4.49 *$ & 0.80 & $4.34^{*}$ & 0.89 & $4.28^{*}$ & 0.97 & $4.40^{*}$ & 0.79 & $4.53^{*}$ & 0.78 & 4.43 & 0.85 \\
\hline 24 & 3.59 & 1.36 & 3.66 & 1.35 & 3.88* & 1.28 & $3.61^{*}$ & 1.34 & $3.47^{*}$ & 1.38 & 3.62 & 1.36 \\
\hline 25 & $3.66^{* *}$ & 2.91 & $3.98^{* *}$ & 2.94 & $3.37^{*}$ & 3.02 & $3.94^{*}$ & 2.85 & $3.94^{*}$ & 2.91 & 3.79 & 2.93 \\
\hline 26 & 5.65 & 2.45 & 5.77 & 2.38 & 5.70 & 2.56 & 5.73 & 2.35 & 5.68 & 2.38 & 5.70 & 2.42 \\
\hline 27 & $8.93^{*}$ & 1.99 & $8.52^{*}$ & 2.32 & $8.44^{*}$ & 2.34 & $8.71^{*}$ & 2.19 & 8.97* & 1.97 & 8.76 & 2.14 \\
\hline 28 & $8.59 *$ & 2.00 & $8.24^{*}$ & 2.29 & 8.36 & 2.18 & 8.52 & 2.13 & 8.47 & 2.10 & 8.45 & 2.13 \\
\hline
\end{tabular}

*Significant at $p<.01 ;{ }^{* *}$ significant at $p<.05$

Notes: 1 = Well informed about the pandemic through parents and carers; $2=$ Well informed about the pandemic through news and media; 3 = Well informed about the pandemic through institutions (schools, universities); $4=$ Well informed about the pandemic through friends and mates; $5=$ Concern to find a solution for family money; $6=$ Worried about money that family has; 7 = Spend time normally before the COVID-19lockdown; $8=$ Spend time during the COVID-19 lockdown; $9=$ Satisfaction with contact with friends; $10=$ Satisfaction with adults let you participate in the conversations about Coronavirus; $11=$ SWB; $12=$ Happy; $13=$ Sad; $14=$ Calm; $15=$ Stressed; $16=$ Full of energy; $17=$ Bored; $18=$ Lonely; $19=$ Worried about being infected by the virus; $20=$ Worried about someone that children know infected by the virus; 21 = Worried about changing status of the study at school; 22 = Worried about someone might hurt the children; $23=$ Worried about what is happening in Indonesia at the moment; $24=$ Worries are heard; $25=$ Did not go to school during the COVID-19 lockdown; 26 = Things that have learned at home; 27 = Solution for Coronavirus; 28 = Solution for feeling safety 
Table 6

ANOVA of Children's and Adolescents' Well-being Variables for Each Group

\begin{tabular}{|c|c|c|c|c|}
\hline Groups & Variables & $d f$ & $F$ & Sig \\
\hline \multirow[t]{28}{*}{ Gender } & Well informed about the pandemic through parents and carers & 1 & 0.307 & .570 \\
\hline & Well informed about the pandemic through news and media & 1 & 0.653 & .419 \\
\hline & Well informed about the pandemic through institutions (schools, universities) & 1 & 3.666 & .056 \\
\hline & Well informed about the pandemic through friends and mates & 1 & 0.000 & .989 \\
\hline & Concern to find a solution for family money & 1 & 10.658 & .001 \\
\hline & Worried about money that family has & 1 & 21.872 & .000 \\
\hline & Spent time normally before the COVID-19 lockdown & 1 & 3.294 & .070 \\
\hline & Spent time during the COVID-19 lockdown & 1 & 0.804 & .370 \\
\hline & Satisfaction with the contact with friends & 1 & 0.879 & .349 \\
\hline & $\begin{array}{l}\text { Satisfaction with adults let you participate in the conversations about } \\
\text { Coronavirus }\end{array}$ & 1 & 0.237 & .627 \\
\hline & SWB & 1 & 6.925 & .009 \\
\hline & Happy & 1 & 4.213 & .040 \\
\hline & Sad & 1 & 37.714 & .000 \\
\hline & Calm & 1 & 110.662 & .000 \\
\hline & Stressed & 1 & 32.286 & .000 \\
\hline & Full of energy & 1 & 2.906 & .088 \\
\hline & Bored & 1 & 21.661 & .000 \\
\hline & Lonely & 1 & 17.874 & .000 \\
\hline & Worried about being infected by the virus & 1 & 26.669 & .000 \\
\hline & Worried about someone that children know infected by the virus & 1 & 30.820 & .000 \\
\hline & Worried about changing status of the study at school & 1 & 17.545 & .000 \\
\hline & Worried that someone might hurt the children & 1 & 43.568 & .000 \\
\hline & Worried about what is happening in Indonesia at the moment & 1 & 11.237 & .001 \\
\hline & Worries are heard & 1 & 0.955 & .329 \\
\hline & Did not go to school during the COVID-19 lockdown & 1 & 4.325 & .038 \\
\hline & Things that I have learned at home & 1 & 0.802 & .371 \\
\hline & Solution for Coronavirus & 1 & 13.189 & .000 \\
\hline & Solution for feeling safety & 1 & 9.571 & .002 \\
\hline \multirow{28}{*}{$\begin{array}{l}\text { School } \\
\text { grade }\end{array}$} & Well informed about the pandemic through parents and carers & 2 & 11.264 & .000 \\
\hline & Well informed about the pandemic through news and media & 2 & 1.139 & .320 \\
\hline & Well informed about the pandemic through institutions (schools, universities) & 2 & 1.066 & .345 \\
\hline & Well informed about the pandemic through friends and mates & 2 & 1.226 & .294 \\
\hline & Concern to find a solution for family money & 2 & 7.650 & .000 \\
\hline & Worried about money that family has & 2 & 4.821 & .008 \\
\hline & Spent time normally before the COVID-19 lockdown & 2 & 5.366 & .005 \\
\hline & Spent time during the COVID-19 lockdown & 2 & 2.524 & .080 \\
\hline & Satisfaction with the contact with friends & 2 & 5.916 & .003 \\
\hline & $\begin{array}{l}\text { Satisfaction with adults let you participate in the conversations about } \\
\text { Coronavirus }\end{array}$ & 2 & 4.300 & .014 \\
\hline & SWB & 2 & 13.128 & .000 \\
\hline & Happy & 2 & 9.334 & .000 \\
\hline & Sad & 2 & 23.989 & .000 \\
\hline & Calm & 2 & 7.352 & .001 \\
\hline & Stressed & 2 & 14.467 & .000 \\
\hline & Full of energy & 2 & 10.969 & .000 \\
\hline & Bored & 2 & 6.171 & .002 \\
\hline & Lonely & 2 & 16.742 & .000 \\
\hline & Worried about being infected by the virus & 2 & 2.756 & .064 \\
\hline & Worried about someone that children know infected by the virus & 2 & 0.725 & .485 \\
\hline & Worried about changing status of the study at school & 2 & 1.284 & .277 \\
\hline & Worried that someone might hurt the children & 2 & 1.193 & .304 \\
\hline & Worried about what is happening in Indonesia at the moment & 2 & 11.885 & .000 \\
\hline & Worries are heard & 2 & 11.796 & .000 \\
\hline & Did not go to school during the COVID-19 lockdown & 2 & 5.463 & .004 \\
\hline & Things that I have learned at home & 2 & 0.052 & .949 \\
\hline & Solution for Coronavirus & 2 & 7.867 & .000 \\
\hline & Solution for feeling safety & 2 & 0.566 & .568 \\
\hline
\end{tabular}


There were significant differences in material well-being according to gender and grade. The girls were significantly more concerned than the boys about finding a solution for family money and were more worried about their family's money (see Table 5). While the elementary students were significantly less concerned about finding solutions for family money and less worried about the amount of money their family had than the middle and high school students (see Table 5).

A total of $65.7 \%$ of the children and adolescents reported that they never met their friends, $69.4 \%$ never played with other people outside the house, $70.0 \%$ used social media several times a day, and 40.7\% reported learning and doing homework as an activity that they did once a day (see Table 7).
Table 8 reported more boys (50.9\%) were going outdoors more than girls (45.8\%), as did more high school students (55\%) than middle school (46.4\%) or elementary school (36.6\%) students.

The high school students were significantly less satisfied with how they spent time before lockdown than the elementary and middle school students. Moreover, Table 5 shows there were no significant differences between gender and grade on their satisfaction with how they spent time during the COVID-19 pandemic.

Regarding the percentage of children and adolescents staying in touch with friends, more girls (96.7\%) and more high school students (94.5\%) reported staying in touch with friends than boys (91.2\%) and middle school (96.1\%) and elementary school students (86.5\%) (see Table 9).

Table 7

Frequency of Activities during COVID-19 Lockdown

\begin{tabular}{|c|c|c|c|c|c|c|c|c|}
\hline & \multicolumn{2}{|c|}{ Never } & \multicolumn{2}{|c|}{ Once a day } & \multicolumn{2}{|c|}{$\begin{array}{l}\text { Several times } \\
\text { a day }\end{array}$} & \multicolumn{2}{|c|}{ Once a week } \\
\hline & $\mathrm{n}$ & $\%$ & $\mathrm{n}$ & $\%$ & $\mathrm{n}$ & $\%$ & $\mathrm{n}$ & $\%$ \\
\hline Helping out in the household & 43 & 2.9 & 517 & 35.1 & 778 & 52.8 & 136 & 9.2 \\
\hline $\begin{array}{l}\text { Taking care of siblings or other family } \\
\text { members }\end{array}$ & 346 & 23.5 & 385 & 26.1 & 673 & 45.7 & 70 & 4.7 \\
\hline $\begin{array}{l}\text { Playing games and doing things I did not } \\
\text { do for a long time (e.g., doing a puzzle) }\end{array}$ & 281 & 19.1 & 393 & 26.7 & 569 & 38.6 & 231 & 15.7 \\
\hline Learning and doing homework & 87 & 5.9 & 600 & 40.7 & 644 & 43.7 & 143 & 9.7 \\
\hline Being bored & 160 & 10.9 & 374 & 25.4 & 751 & 50.9 & 189 & 12.8 \\
\hline Watching TV, Netflix, or streaming & 84 & 5.7 & 451 & 30.6 & 808 & 54.8 & 131 & 8.9 \\
\hline Doing sport & 255 & 17.3 & 532 & 36.1 & 175 & 11.9 & 512 & 34.7 \\
\hline Spending time with family & 27 & 1.8 & 344 & 23.3 & 1,064 & 72.2 & 39 & 2.6 \\
\hline $\begin{array}{l}\text { Playing or hanging out inside the house } \\
\text { with other people }\end{array}$ & 765 & 51.9 & 236 & 16.0 & 285 & 19.3 & 188 & 12.8 \\
\hline $\begin{array}{l}\text { Playing or hanging out outside the house } \\
\text { with other people }\end{array}$ & 1,023 & 69.4 & 115 & 7.8 & 83 & 5.6 & 253 & 17.2 \\
\hline Playing computer games & 505 & 34.3 & 304 & 20.6 & 460 & 31.2 & 205 & 13.9 \\
\hline Using social media & 63 & 4.3 & 340 & 23.1 & 1,032 & 70.0 & 39 & 2.6 \\
\hline $\begin{array}{l}\text { Speaking with people on a voice call or } \\
\text { video call, or text message }\end{array}$ & 91 & 6.2 & 418 & 28.4 & 706 & 47.9 & 259 & 17.6 \\
\hline Doing nothing or relaxing & 452 & 30.7 & 442 & 30.0 & 399 & 27.1 & 181 & 12.3 \\
\hline Meeting friends & 969 & 65.7 & 126 & 8.5 & 93 & 6.3 & 286 & 19.4 \\
\hline Reading & 125 & 8.5 & 536 & 36.4 & 583 & 39.6 & 230 & 15.6 \\
\hline Praying & 9 & 0.6 & 215 & 14.6 & 1,232 & 83.6 & 18 & 1.2 \\
\hline
\end{tabular}


Table 8

Percentage of Children and Adolescents Reporting that They Went Outdoors during the COVID-19 Lockdown by Gender and School Grade

\begin{tabular}{lrrrrrrrr}
\hline & \multicolumn{2}{c}{ Yes } & \multicolumn{2}{c}{ No } & \multicolumn{2}{c}{ Don't know } & \multicolumn{2}{c}{ Total } \\
\cline { 2 - 9 } & $\mathrm{n}$ & $\%$ & $\mathrm{n}$ & $\%$ & $\mathrm{n}$ & $\%$ & $\mathrm{n}$ & $\%$ \\
\hline Girls & 404 & 45.8 & 457 & 51.8 & 22 & 2.5 & 883 & 100 \\
Boys & 301 & 50.9 & 276 & 46.7 & 14 & 2.4 & 591 & 100 \\
Elementary & 144 & 36.6 & 242 & 61.6 & 7 & 1.8 & 393 & 100 \\
Middle school & 179 & 46.4 & 193 & 50.0 & 14 & 3.6 & 386 & 100 \\
High school & 382 & 55.0 & 298 & 42.9 & 15 & 2.2 & 695 & 100 \\
\hline Total & 705 & 47.8 & 733 & 49.7 & 36 & 2.4 & 1,474 & 100 \\
\hline
\end{tabular}

Table 9

Percentage of Children and Adolescents Reporting that They Stayed in Touch with Friends by Gender and School Grade

\begin{tabular}{lrrrrrrrr}
\hline & \multicolumn{2}{c}{ Yes } & \multicolumn{2}{c}{ No } & \multicolumn{2}{c}{ Don't know } & \multicolumn{2}{c}{ Total } \\
\cline { 2 - 9 } & $\mathrm{n}$ & $\%$ & $\mathrm{n}$ & $\%$ & $\mathrm{n}$ & $\%$ & $\mathrm{n}$ & $\%$ \\
\hline Girls & 854 & 96.7 & 25 & 2.8 & 4 & 0.5 & 883 & 100 \\
Boys & 539 & 91.2 & 49 & 8.3 & 3 & 0.5 & 591 & 100 \\
Elementary & 340 & 86.5 & 49 & 12.5 & 4 & 1.0 & 393 & 100 \\
Middle school & 371 & 96.1 & 13 & 3.4 & 2 & 0.5 & 386 & 100 \\
High school & 682 & 98.1 & 12 & 1.7 & 1 & 0.1 & 695 & 100 \\
\hline Total & 1,393 & 94.5 & 74 & 5.0 & 7 & 0.5 & 1,474 & 100 \\
\hline
\end{tabular}

Children and adolescents were unable to meet with friends in person during the lockdown and used modes of online communication instead, as presented in Table 10. The most frequently used modes of communication were WhatsApp (86.8\%), video calls (60.5\%), and Instagram (55.8\%).

Among the three school grade groups, the elementary students reported being more unsatisfied with their contact with friends during lockdown than the middle school and high school students (see Table 5).

The high school students displayed higher mean scores than the elementary students (see Table 5), suggesting they perceived those adults listened to them more frequently in conversations about Coronavirus.
Regarding SWB and the PNAS, there were significant gender differences for all variables, except for "full of energy". Table 5 shows boys were significantly had higher mean scores than girls on SWB and PA, while girls displayed higher mean scores than boys on NA. These results suggest that girls were sadder, more stressed, more bored, and lonelier than boys during the lockdown.

Table 5 shows significant differences between the school grades on all SWB variables and PNAS. High school students reported higher scores on NA than elementary and middle school students, suggesting that the high school students were sadder, more stressed, more bored, and lonelier than the elementary and middle students. Elementary students reported significantly higher mean scores than middle and high 
school students on SWB, being happy, and full of energy. Middle school students displayed significantly higher mean scores than elementary and high school students on being calm.

Table 5 displays significant differences in the variables for worrying according to gender and school grade. Girls reported feeling more worried than boys about the effects of the pandemic on different people. The highest mean score in girls $(\mathrm{M}=7.66$; $\mathrm{SD}=2.55)$ was for the possibility that someone they knew may become infected by the virus. In contrast, the highest mean score in boys $(\mathrm{M}=6.91 ; \mathrm{SD}=2.68)$ concerned family money.

High school students were more worried than middle and elementary students and reported being unsatisfied with how they normally spent time before lockdown.
Regarding school closure or not attending school during the lockdown, girls reported being significantly less satisfied than boys. In contrast, elementary students reported being more unsatisfied than middle and high school students (see Table 5).

The modes of remote learning are presented in Table 11.

Girls displayed significantly higher mean scores than boys on concern about finding a solution for Coronavirus, family money, and feeling safe. In comparison, high school students reported feeling more concerned about finding solutions to Coronavirus and family money than middle and elementary students.

\section{Table 10}

Percentage of Modes of Communication Used to Keep in Touch with Friends during COVID-19 Lockdown

\begin{tabular}{lrrrr}
\hline & \multicolumn{2}{c}{ Yes } & \multicolumn{3}{c}{ No } \\
\cline { 2 - 5 } & $\mathrm{n}$ & $\%$ & $\mathrm{n}$ & $\%$ \\
\hline Voice call & 643 & 43.6 & 831 & 65.4 \\
Video call & 892 & 60.5 & 582 & 39.5 \\
WhatsApp & 1,280 & 86.8 & 194 & 13.2 \\
Instagram & 823 & 55.8 & 651 & 44.2 \\
Facebook & 203 & 13.8 & 1,271 & 86.2 \\
Line & 422 & 28.6 & 1,052 & 71.4 \\
Twitter & 202 & 13.7 & 1,272 & 86.3 \\
Hanging around the neighborhood & 199 & 13.5 & 1,275 & 86.5 \\
Not at all & 31 & 2.1 & 1,443 & 97.9 \\
Zoom & 29 & 2.0 & 1,445 & 98.0 \\
Online games & 12 & 0.8 & 1,462 & 99.2 \\
Telegram & 7 & 0.5 & 1,467 & 99.5 \\
email & 1 & 0.1 & 1,473 & 99.9 \\
Google meet & 7 & 0.5 & 1,467 & 99.5 \\
Discord & 7 & 0.5 & 1,467 & 99.5 \\
Google classroom & 1 & 0.1 & 1,473 & 99.9 \\
Snapchat & 1 & 0.1 & 1,473 & 99.9 \\
Webex & 1 & 0.1 & 1,473 & 99.9 \\
\hline
\end{tabular}


Table 11

Percentages of Modes of Learning from Home

\begin{tabular}{lrrrr}
\hline & \multicolumn{2}{c}{ Yes } & $\mathrm{n}$ & No \\
\cline { 2 - 5 } & $\mathrm{n}$ & $\%$ & 179 & 12.1 \\
\hline Online learning & 1,295 & 87.9 & 635 & 43.1 \\
WhatsApp learning class & 839 & 56.9 & 1,047 & 71.0 \\
Learning through national TV & 427 & 29.0 & 1,022 & 69.3 \\
Learning with parents or carers & 452 & 30.7 & 771 & 52.3 \\
Learning by myself & 703 & 47.7 & 1,240 & 84.1 \\
Learning with siblings & 234 & 15.9 & 1,466 & 99.5 \\
Learning with friends & 8 & 0.5 & 1,463 & 99.3 \\
Reading books & 11 & 0.7 & 1,471 & 99.8 \\
Tutorial learning with teacher & 3 & 0.2 & 1,473 & 99.9 \\
Learning with family members & 1 & 0.1 & & \\
\hline
\end{tabular}

\section{Discussion}

This study aimed to present children's and adolescents' reports on their QoL during the COVID-19 pandemic in Indonesia.

The results show that the average SWB item scores are between 70.55 and 77.2 (see Table 5). According to Cummins (2014), SWB ranges from 60 to 90 , with a mean of 75 when projected on a 100-point scale. Therefore, the scores presented in Table 5 (70.55 to 77.2) are relatively average (Cummins, 2014), meaning Indonesian children and adolescents maintained their level of SWB and adapted to adverse situations during the COVID19 lockdown. These results align with those of a study conducted in Turkey reporting QoL scores of $73.91 \pm 8.44$ in children (Adıbelli \& Sümen, 2020).

Boys displayed significantly higher mean SWB scores than girls, and elementary students displayed significantly higher SWB scores than middle and high school students (see Table 5). These results are consistent with a German study that revealed a higher proportion of girls reporting low QoL than boys during the pandemic (Ravens-Sieberer et al., 2021). However, this study's results on school grades contrast with those of Ravens-Sieberer et al. (2021), where more younger children reported significantly low QoL than older children.

Casas and González-Carrasco (2019) found that the children's SWB decreases with age from 10 to 16 years old. This result aligns with the current study showing that younger children display significantly higher mean SWB scores than older children, and high school students display significantly lower SWB scores (see Table 5).

The five domains suggested by Felce and Perry (1997) were used in the current study to describe the children's and adolescents' QoL. Regarding material well-being, girls and older children reported more concern about finding a solution for family money issues and were more worried about the money their family has, as seen in Table 5. In April 2020, 5,2 million Indonesians lost their jobs and fell into poverty (Akhlas, 2020). 
UNICEF (2021) reported that the poverty rate for Indonesian children rose by $14 \%$, meaning that children were affected by the economic fallout during the pandemic. A parent losing their job affected the economic situation at home and forced parents to reduce consumption.

Physical well-being includes activities to maintain health and fitness (Wallander et al., 2001). Table 7 shows that $50.9 \%$ of children reported they were bored several times a day, suggesting a potential lack of physical activities in which to engage during the lockdown. Only $34.7 \%$ of children reported participating in a sport once per week. Schools were closed during the pandemic, meaning children were confined at home, with restrictions on outdoor activities, playing, and interacting with friends. However, playing outdoors with friends enhances children's social, emotional, and physical development (Wilson, 2007).

The findings from this study align with suggestions by Lesser and Nienhuis (2020) that people who engage in outdoor physical activity show increased well-being and have lower anxiety than those who spend less time on outdoor physical activity. These results suggest that children need to spend more time doing physical activities in order to maintain their QoL.

Regarding social well-being, $65.7 \%$ of the participants reported never meeting with friends during the lockdown (see Table 7). However, 94.5\% reported that they stayed in touch with friends (see Table 9), with $86.8 \%$ reporting that they used WhatsApp and $60.5 \%$ used video calls (see Table 10). Yet despite staying in touch with friends, they reported not being fully satisfied with the contact; the mean scores were relatively moderate (4.92 to 5.47 ) on a $0-10$ scale, as displays in Table 5. In line with the findings from this study, another study revealed that high and frequent use of social media during the pandemic was associated with low QoL (Geirdal et al., 2021).

The participants reported feeling dissatisfied with not going to school (mean scores from 3.37 to 3.94 on a $0-10$ scale; see Table 5 since the closure of schools also prevented them from meeting with friends. Several studies have revealed that along with its role in providing academic support for children to gain good marks, school is also a place for them to make friends and socialize with other children (Ghosh et al., 2020; González-Carrasco et al., 2017).

Regarding emotional well-being, being bored accounted for the highest affect mean scores among the children and adolescents, with girls reporting being significantly more bored than boys and high school students significantly more bored than middle and elementary school students (see Table 5). This boredom reflects the closure of schools, the inability to participate in various physical activities, and changes in communication during the pandemic. These findings are in line with WHO (World Health Organization, 2020a).

The participants reported feeling more satisfied with how they spent their time before rather than during the pandemic (see results in Table 5). These results suggest that their boredom may have been associated with a lack of access to various outdoor activities. Jackson et al. (2021) found that individuals who participated in outdoor activities reported smaller declines in SWB.

Girls reported feeling sadder, more stressed, more bored, and lonelier than boys during the 
lockdown. High school students were sadder, more stressed, more bored, and lonelier than elementary and middle students. Elementary students had more energy than middle and high school students, and middle school students were calmer than elementary and high school students.

Productive well-being includes competence and productivity (Wallander et al., 2001). The participants reported they were dissatisfied with not going to school (mean 3.37-3.94 on a scale of $0-10$ ) and the things they learned at home (mean $5.68-5.73$ on a $0-10$ scale) (see Table 5). The closure of schools forced parents to take greater responsibility in terms of teaching their children at home and juggling house chores and professional responsibilities while also working from home. According to Garbe et al. (2020), parents faced difficulties in supporting their children to achieve learning outcomes, which is consistent with the results from the current study (see Table 5).

Elementary and middle school students reported that they felt well informed about the pandemic through parents and carers. In contrast, high school students reported feeling more well informed through news and media (see Table 5). These results suggest that younger children are more dependent on their parents and carers for information while older children, in comparison, are more autonomous in searching for information. These results also show that schools did not provide good information about COVID-19 to their students.

\section{Conclusion}

Indonesian children seem to have maintained their level of SWB and adapted to adverse situations despite the COVID-19 lockdown. In this study, boys displayed significantly higher mean SWB scores than girls, and younger children displayed significantly higher mean SWB scores than older children.

The participants reported being bored because they did not have access to various physical activities, and they were dissatisfied with school closures, which restricted them from socializing and interacting with their friends. Although they remained in contact with friends via social media, they reported not being satisfied with their contact.

Girls and high school students were sadder, more stressed, more bored, and lonelier than boys and elementary and middle school students.

Children reported that they did not feel productive during the COVID-19 pandemic. They reported being dissatisfied with not going to school and having to learn at home.

This study has some limitations. First, it does not use a representative sample of Indonesian children, and therefore the results cannot be generalized. Second, it focuses only on children and adolescents aged between 10 and 18 years. Therefore, this study cannot explain the QoL of children under the age of 10 during the COVID-19 pandemic in Indonesia. Future research should investigate factors related to children's QoL during the pandemic.

Parents should have allowed their children to spend a greater amount of time on physical activities during the COVID-19 pandemic to promote their QoL and to help them stay on course at home. Teachers should also have creatively assigned physical activities for online study.

Parents should also have provided various modes of communication to improve the social 
well-being of children who reported not being satisfied with their contact with friends.

Children and adolescents can do different physical activities and use various modes of communication with their friends to promote their QoL.]

\section{References}

Adıbelli, D., \& Sümen, A. (2020). The effect of the coronavirus (COVID-19) pandemic on health-related quality of life in children. Children and Youth Services Review, 119, 105595. https://doi.org/10.1016/j.childyouth.2020.105595

Akhlas, A. W. (2020, April 15). Millions to lose jobs, fall into poverty as Indonesia braces for recession. The Jakarta Post. https://www.thejakartapost.com/news/2020/04/14/millions-to-lose-jobs-fallinto-poverty-as-indonesia-braces-for-recession.html

Anindyajati, G., Wiguna, T., Murtani, B. J., Christian, H., Wigantara, N. A., Putra, A. A., Hanafi, E., Minayati, K., Ismail, R. I., Kaligis, F., Savitri, A. I., Uiterwaal, C. S. P. M., \& Diatri, H. (2021). Anxiety and its associated factors during the initial phase of the COVID-19 pandemic in Indonesia. Frontiers in Psychiatry, 12, 1-10. https://doi.org/10.3389/fpsyt.2021.634585

Ben-Arieh, A., Casas, F., Frønes, I., \& Korbin, J. E. (2014). Multifaceted concept of child well-being. In A. Ben-Arieh, F. Casas, I. Frønes, \& J. E. Korbin (Eds.), Handbook of child well-being (pp. 1-27). Springer. https://doi.org/10.1007/978-90-481-9063-8_134

Berita Satu. (2020, March 2). Indonesia confirms first coronavirus cases in its territory. Jakarta Globe. https://jakartaglobe.id/news/indonesia-confirms-first-coronavirus-cases-in-its-territory/

Borualogo, I. S., \& Casas, F. (2019). Adaptation and validation of the Children's Worlds Subjective WellBeing Scale (CW-SWBS) in Indonesia. Jurnal Psikologi, 46(2), 102. https://doi.org/10.22146/jpsi.38995

Borualogo, I. S., \& Casas, F. (2021a). The relationship between frequent bullying and subjective wellbeing in Indonesian children. Population Review, 60(1), 26-50. https://doi.org/10.1353/prv.2021.0002

Borualogo, I. S., \& Casas, F. (2021b). Subjective well-being of bullied children in Indonesia. Applied Research in Quality of Life, 16(2), 753-773. https://doi.org/10.1007/s11482-019-09778-1

Borualogo, I. S., Gumilang, E., Mubarak, A., Khasanah, A. N., Wardati, M. A., Diantina, F. P., Permataputri, I., \& Casas, F. (2019). Process of translation of the Children's Worlds Subjective Well-being Scale in Indonesia. Proceedings of the Social and Humaniora Research Symposium (SoRes 2018), 180 183. https://doi.org/10.2991/sores-18.2019.42

Cao, W., Fang, Z., Hou, G., Han, M., Xu, X., Dong, J., \& Zheng, J. (2020). The psychological impact of the COVID-19 epidemic on college students in China. Psychiatry Research, 287, 112934. https://doi.org/10.1016/j.psychres.2020.112934

Casas, F., \& González-Carrasco, M. (2019). Subjective well-being decreasing with age: New research on children over 8. Child Development, 90(2), 375-394. https://doi.org/10.1111/cdev.13133

Casas, F., \& González, M. (2017). School: One world or two worlds? Children's perspectives. Children and Youth Services Review, 80,157-170. https://doi.org/10.1016/j.childyouth.2017.06.054 
Cummins, R. A. (2014). Understanding the well-being of children and adolescents through homeostatic theory. In A. Ben-Arieh, F. Casas, I. Frønes, \& J. E. Korbin (Eds.), Handbook of child well-being (pp. 635-661). Springer. https://doi.org/10.1007/978-90-481-9063-8_152

Fegert, J. M., Vitiello, B., Plener, P. L., \& Clemens, V. (2020). Challenges and burden of the Coronavirus 2019 (COVID-19) pandemic for child and adolescent mental health: a narrative review to highlight clinical and research needs in the acute phase and the long return to normality. Child and Adolescent Psychiatry and Mental Health, 14(1), 20. https://doi.org/10.1186/s13034-020-00329-3

Felce, D., \& Perry, J. (1997). Quality of life: The scope of the term and its breadth of measurement. In R. I. Brown (Ed.), Quality of life for people with disabilities (2nd ed., pp. 56-71). Stanley Thornes (Publishers) Ltd.

Fiscal Policy Agency Ministry of Finance Republic of Indonesia, \& UNICEF. (2021). Policy brief: The impact of COVID-19 on child poverty and mobility in Indonesia. In UNICEF \& Fiscal Policy Agency Ministry of Finance Republic of Indonesia.

Garbe, A., Ogurlu, U., Logan, N., \& Cook, P. (2020). Parents' experiences with remote education during COVID-19 school closures. American Journal of Qualitative Research, 4(3), 45-65. https://doi.org/10.29333/ajqr/8471

Geirdal, A. Ø., Ruffolo, M., Leung, J., Thygesen, H., Price, D., Bonsaksen, T., \& Schoultz, M. (2021). Mental health, quality of life, wellbeing, loneliness and use of social media in a time of social distancing during the COVID-19 outbreak. A cross-country comparative study. Journal of Mental Health, 30(2), 148-155. https://doi.org/10.1080/09638237.2021.1875413

Ghosh, R., Dubey, M. J., Chatterjee, S., \& Dubey, S. (2020). Impact of COVID-19 on children: Special focus on the psychosocial aspect. Minerva Pediatrica, 72(3), 226-235. https://doi.org/10.23736/S0026-4946.20.05887-9

González-Carrasco, M., Casas, F., Malo, S., Viñas, F., \& Dinisman, T. (2017). Changes with age in subjective well-being through the adolescent years: Differences by gender. Journal of Happiness Studies, 18, 63-88. https://doi.org/10.1007/S10902-016-9717-1

Jackson, S. B., Stevenson, K. T., Larson, L. R., Peterson, M. N., \& Seekamp, E. (2021). Outdoor activity participation improves adolescents' mental health and well-being during the COVID-19 pandemic. International Journal of Environmental Research and Public Health, 18(5), 2506. https://doi.org/10.3390/ijerph18052506

Lesser, I. A., \& Nienhuis, C. P. (2020). The impact of COVID-19 on physical activity behavior and wellbeing of Canadians. International Journal of Environmental Research and Public Health, 17(11), 3899. https://doi.org/10.3390/ijerph17113899

Mitra, R., Waygood, E. O. D., \& Fullan, J. (2021). Subjective well-being of Canadian children and youth during the COVID-19 pandemic: The role of the social and physical environment and healthy movement behaviours. Preventive Medicine Reports, 23, 101404. https://doi.org/10.1016/j.pmedr.2021.101404

News Desk. (2020, March 27). Indonesia to issue lockdown regulation as COVID-19 cases continue to soar. The Jakarta Post.

Odriozola-González, P., Planchuelo-Gómez, Á., Irurtia, M. J., \& de Luis-García, R. (2020). Psychological effects of the COVID-19 outbreak and lockdown among students and workers of a Spanish university. Psychiatry Research, 290. https://doi.org/10.1016/J.PSYCHRES.2020.113108 
Orgilés, M., Morales, A., Delvecchio, E., Mazzeschi, C., \& Espada, J. P. (2020). Immediate psychological effects of the COVID-19 quarantine in youth from Italy and Spain. Frontiers in Psychology, 11. https://doi.org/10.3389/FPSYG.2020.579038

Ravens-Sieberer, U., Kaman, A., Erhart, M., Devine, J., Schlack, R., \& Otto, C. (2021). Impact of the COVID19 pandemic on quality of life and mental health in children and adolescents in Germany. European Child \& Adolescent Psychiatry, 1-11. https://doi.org/10.1007/S00787-021-01726-5

Rees, G., Savahl, S., Lee, B. J., \& Casas, F. (Eds.). (2020). Children's views on their lives and well-being in 35 countries: A report on the children's worlds study, 2016-19.

Setiawati, Y., Wahyuhadi, J., Joestandari, F., Maramis, M. M., \& Atika, A. (2021). Anxiety and resilience of healthcare workers during COVID-19 pandemic in Indonesia. Journal of Multidisciplinary Healthcare, 14, 1-8. https://doi.org/10.2147/JMDH.S276655

Sipahutar, T. (2020, March). Indonesia closes schools across archipelago as virus cases spike. Bloomberg.

Sunjaya, D. K., Herawati, D. M. D., \& Siregar, A. Y. M. (2021). Depressive, anxiety, and burnout symptoms on health care personnel at a month after COVID-19 outbreak in Indonesia. BMC Public Health, 21(1), 1-8. https://doi.org/10.1186/S12889-021-10299-6

UNDP. (2021). World Population Dashboard. United Nations Population Fund.

Wallander, J. L., Schmitt, M., \& Koot, H. M. (2001). Quality of life measurement in children and adolescents: Issues, instruments, and applications. Journal of Clinical Psychology, 57(4), 571585. https://doi.org/10.1002/JCLP.1029

Wilson, R. (2007). Nature and young children: Encouraging creative play and learning in natural environments. In Nature and Young Children: Encouraging Creative Play and Learning in Natural Environments. Routledge. https://doi.org/10.4324/9780203940723

World Health Organization. (2020a). \#HealthyAtHome - Healthy parenting. World Health Organization. https://www.who.int/campaigns/connecting-the-world-to-combatcoronavirus/healthyathome/healthyathome---healthy-parenting

World Health Organization. (2020b). Listings of WHO's response to COVID-19. World Health Organization. https://www.who.int/news/item/29-06-2020-covidtimeline 
This page has been intentionally left blank. 